\title{
KARL MARLO, GUILD SOCIALISM, AND THE REVOLUTIONS OF I 848
}

The notion that the German liberals of 1848 failed because they were mere men of ideas and hence incapable of managing the grim realities of power politics has become dogma. We tend to accept this interpretation unthinkingly, I suspect, because it fits so well our modern anti-idealist bias in favor of the "practical realist" in politics - one, that is to say, who is adept at maneuvering safely among existing forces without attempting to add the force of ideals and hope. In his recent and excellent book, however, Mr. Theodore S. Hamerow has shown that the liberals of 1848 failed not because they were impractical but because they were too practical. ${ }^{1}$ Indeed, so single-mindedly did the liberals push their own practical political and economic interest, Mr. Hamerow informs us, that they cut off their ties with those classes - the peasants and workers - whose violence had made the revolutions successful.

The peasants wanted freedom from manorial dues, and where that had been granted they hoped to be relieved of the crushing burden of commutation fees, mortgages, and rents. The liberals would not aid the peasants by expropriating the landed classes, because such a denial of the right of private property would set a precedent threatening to the liberals themselves. Similarly, the liberals could not satisfy the demands of the German workers. For, as Mr. Hamerow reminds us, the majority of German workers were not to be found in the ranks of the relatively satisfied industrial proletariat, but among the more numerous, more dissatisfied and more revolutionary guild and craft workers of what was still in 1848 a pre-industrial order. The practical need of the liberals for free enterprise found its most implacable opposition among those who had built the barricades and carried arms against King and aristocracy in the Spring of 1848 - the masters and journeymen of the guilds. The guildsmen saw their prerogatives, rights, and profits

1 Theodore S. Hamerow, Restoration, Revolution, Reaction: Economics and Politics in Germany, 1815-1871, Princeton University Press, 1958. 
threatened by the spectre of unregulated competition and the might of unfettered masses of capital in the hands of ruthless entrepreneurs, ready and able to seize the markets of the guilds. From the moment when the liberals of the Frankfort Parliament established as fundamental laws the twin rights of private property and free enterprise, they were no longer able to summon the support of the revolutionary forces of Germany and fell easy victims to the reaction. ${ }^{1}$

To understand the course of the revolutions in Germany, then, it is necessary to know the aims of the guildsmen and something of their attempts to further those aims. During the upheavals of 1848 the guildsmen assembled in order to persuade the Frankfort Parliament and the individual states to legislate against the new industries which were already driving some of the masters out of their once secure markets. In Berlin, Hamburg, Frankfort, Vienna, Munich, Cologne, and Breslau, as well as many smaller cities and towns, masters and journeymen met and argued, formulated demands and issued petitions. It was not exaggeration but fact - as the thousands of petitions prove when, as a preface to its recommendations, one group of guildsmen wrote:

"As the spring sun of 1848 awoke the peoples of Europe out of their long sleep, the industrial classes of Germany also awoke in order to take part in the general struggle for freedom and independence. They saw the necessity for a total reshaping of our social circumstances, and decided to speak out their views about the future order." 2

But who could hope for success in the Spring of 1848 if he intended only to defend ancient privilege? If the guilds were to play an important role in Germany's future, they would have to stand for more than simply the selfish demands of their class. Moreover, the power and social value of large-scale industrial organization were rapidly becoming effective and evident in the eighteen-forties; the road back was closed; the future demanded more than nostalgia; it would not accept mere selfishness. As the above quotation indicates, some of the guildsmen were aware of the need for a more general appeal and a wider vision; that they were was largely due to the efforts of one Karl

1 Ibid., p. 155.

2 Beschluesse des Allgemeinen Deutschen Arbeiterkongresses zu Frankfurt a.M. As reprinted in, W. Biermann, Karl Winkelblech (Karl Marlo), Leipzig, 1909, II, Anhang I, p. 44 r. 
Marlo - the social theorist of the German guild movement during the years of revolution. ${ }^{1}$

Marlo was not a guildsman; he was a chemistry teacher in a trade school in Kassel, Kurhessen. In the Foreword to the first volume of his life-work he related the experience which aroused in him a passion for social reform which was not to leave him until his death in 1865 . In 1843 he was in Norway, collecting materials for a book on industrial chemistry:

As I looked down from a hill one morning at surroundings capable of offering competition to the most beautiful areas of the Alps a German worker - recognizing me as a countryman of his came to me and asked if I would take care of a few matters for him in the homeland. Encouraged by my willingness, he sketched for me a gripping description of his experiences and the poverty in which he and his comrades languished. Why is it, I asked myself, that this paradise spread out before my eyes hides so much misery? Is nature the source of these sufferings or is it man that is guilty? Like so many scientists, I had heretofore directed my eyes in the factories to the furnaces and the machines, not to the men, to the products of human industry, not the producers, and therefore I was a total stranger to that great empire of misery which is the basis of our superficially decorative civilization. The convincing words of the worker made me feel the complete nothingness of all my scientific attempts, and in a few moments the decision ripened in me to investigate the suffering of mankind, its causes and its cures." 2

From then on, Marlo spent most of his spare time searching through the works of the Classical Economists - those primers for all radicals and studying the principles of the French utopian Socialists. He once boasted, however, that before he began his reading he had discerned the major changes needed if society was to be reformed through an investigation of economic conditions in his own province, where he spent many hours visiting the workshops of the guilds. ${ }^{3}$ Consequently Marlo did not discover the causes of the worker's misery in industrial society, for Kurhessen had not experienced industrialization; instead,

1 His name was Karl Winkelblech, but with one exception (a chemistry textbook) he published under the name of Karl Marlo.

Karl Marlo, Untersuchungen ueber die Organisation der Arbeit; oder, System der Weltoekonomie, Kassel, Appel, I853, I, Part two, Foreword, pp. III-IV.

Ibid., p. V. 
Marlo found what he hoped would be an alternative to the industrialism of France and England - the guild system.

After Bavaria, Kurhessen had the highest proportion of guildsmen to population in Germany. ${ }^{1}$ Marlo's native province was a land of small villages surrounded by carefully cultivated fields and inhabited by peasants and the master tailors, smiths, bakers, carpenters, and shoemakers of the guilds, who, with their journeymen and apprentices, formed a comprehensive guild system as yet undisturbed by free enterprise and still protected by ancient monopolies and a determined insistence on prerogative and precedent. It was here that Marlo carried on his researches and here that he found an "organization of labor" whose principles he hoped to see embodied in an economic order which would protect Germany from the ravages of the Industrial Revolution.

And, as far as Marlo was concerned, ravages was the right word. Lacking any first-hand knowledge of industrial society, Marlo was all the more subject to the utopian Socialists dismal view of capitalism, a view not made more optimistic by his reading of Ricardo. Consequently, Volume One, Part one of Marlo's Organisation der Arbeit (published in 1850 but in manuscript before the revolutions of 1848 ) presents the most damaging criticisms of the utopian Socialists as unqualified fact.

Conceding that tremendous productive powers had been unleashed by the use of machinery and the increasing division of labor, Marlo insisted with Fourier that the task of the worker had become so simple as to deprive him of the pleasure in his work enjoyed by the craftsman of an older economic system. He decried the passing of the independent master: "The greater number of workers have lost their social independence and have been transformed into an army of dependent workers." 2 To start a new enterprise, Marlo argued, great masses of capital are needed, with the immoral consequence that only those who have wealth can hope to gain more. In modern industrial societies:

"Industriousness, talent, and ability are no longer the means for founding a business; for capital is needed if these virtues are to have any effect, and they are not the basis on which capital is extended. Nothing remains for even the most intelligent to do, but to surrender his social independence and put himself in the service

1 Gustav Schmoller, Zur Geschichte der Deutschen Kleingewerbe im I gten Jahrhundert, Halle, $1870,307$.

${ }^{2}$ Marlo, op. cit., I. Part One, 53. 
of the capital-rich entrepreneurs, and leave to them the greater part of the fruit of his labor." 1

Still more terrible are the effects of the gradual lowering of wages. Unlike the guildsmen, Marlo argued, the workers have no standard by which to judge their probable future income. Who can blame them if they give up all attempts to limit the size of their families in the vain hope of increasing their wealth? And upon the rapid increase of population depends the decrease of wages. Looking at the history of industrial society as presented to him by the utopian Socialists, Marlo observed, "population grew swiftly... the supply of workers increased beyond the demand, wages sank to the lowest possible level, and must ...remain there in the future." 2

To Marlo, the most dreadful scourges of all were the periodic commercial crises. They are, he insisted, the result of the miscalculation of entrepreneurs who deal in such large quantities and supply such vast and distant markets, that they cannot foresee the amount of goods those markets can absorb. The guilds produced for a local market and knew with certainty how much they could sell. Of course, Marlo continued, there never will come a day when too much is produced, for the demands of men are insatiable. But as wages are driven down, the consuming power of the masses is decreased, with the result that more is produced than can be sold, businesses fail, workers are fired, and hunger stalks the land.

Marlo had read Engels as well as those who described the lot of the proletariat in France; and he concluded that filth, slavery, and starvation must be the permanent fate of the workers under capitalism. ${ }^{3}$ It is not difficult to imagine the powerful surge of protest that must have come from radicals when they read such descriptions of the lives of the workers. It is difficult, however, to visualize their terrible effects on men like Marlo, men who believed that such were the lives of all factory workers and that with the extension of industrialism, all workers would come to share that fate. When Marlo read the complacent accusations which held that the workers deserve no better because they are a lazy and stupid lot, he grew hot with anger. If the workers are not virtuous, he asked: "Are dishonesty, greed, gluttony, selfishness, hardness, and cold contempt for all the duties of love, by which the bourgeoisie are characterized, to be called virtues?" 4 Just

\footnotetext{
1 Ibid., 73. $\quad 3$ Ibid., rogff.

Ibid., s5. 1 Ibid., IIs.
} 
who are these Geldherren? They are the calculating speculators who deal in futures and plunder society through their manipulations of the stock market. They are the ones who give terrible force to the so-called "law of supply and demand" by holding back their products until prices are driven up. Like all utopians, Marlo was a frank moralist, so that unlike the Marxists he did not maintain that these "laws" of capitalism have force because they are the inevitable results of the presumed "objective relationships of production", but because those who determine the relationships of production "know but one business, profit, and but one goal for all their activities, the increase of their treasure." 1

In short, Marlo was aware of the classic criticisms of the utopian Socialists, and he added little to them. The iron law of wages, the progressive immiserization of the proletariat, the labor theory of value (but not of price) they are all to be found in his Organisation der Arbeit, along with the laws of population increase which seem to make a constant surplus of workers inevitable, and thus give impetus to the whole.

Like so many Socialists, but especially because of his sympathy with the guilds, Marlo greatly overestimated the power of those who owned masses of capital and consequently exaggerated not so much the unfairness as the inflexibility of early nineteenth century capitalism. It was not true that the profits of an entrepreneur were in direct ratio to the amount of capital he possessed, nor could it be said that talent without capital must go unrewarded. An entrepreneur required only enough capital to cover his investments and losses and there were ways of acquiring it. A man with a new idea, invention, or product, could gain capital by borrowing or combining with others, and a large enterprise might be built up gradually through the reinvestment of profits. Small businesses and even the guilds themselves need not necessarily succomb to large concerns; often enough they prospered by supplying such concerns or their workers. As for Marlo's attempts to prove the necessity of a constant decrease of wages to the subsistence level because of population increases, he assumed without benefit of statistics that population growth outstripped the employment capacity of industry and that, under capitalism, it must always do so. Again, one cannot assume that the owner or entrepreneur expropriates all surplus value unless one has first shown that all industrial workers receive a wage equal to the "subsistence minimum" - itself too vague to define. But even if one has shown that, one has not demonstrated that such must always be the fate of all workers under capitalism. Like

1 Ibid., 71. 
the Utopians who first made this criticism of industrial society, Marlo transformed contemporary fact - starvation wages, chronic unemployment, and periodic crises - into necessary result. Still, Marlo and the Utopians should not be dismissed out-of-hand for this error, after all, it remained for the Marxists to make the destruction of capitalism depend on the necessary realization of such abstract, inherent, and inevitable "contradictions" of capitalism. Marlo's fundamental error, of course, lies in the fact that the only way to prove or disprove any of these "laws" of capitalism was to find out what was actually happening where the Industrial Revolution was under way, and this he never did; he depended solely on theoretical works.

It is difficult now to sympathize with the terror Marlo felt when he observed what he took to be the effects of the Industrial Revolution. Once his fears become real to us, however, we are able to understand why he thought that only the most radical reform of society would be of any permanent value. He visualized the coming of the men of the new disorder; armed with the might of capital, machinery, and steam; contemptuous of the petty restrictions of the guild system, they would easily destroy their weak competitors in the guilds and with them the peace of the old order, until nothing remained but exploitation, arrogance, and luxury, pitted against helplessness, hate, and misery. Look at France and England, he asked his readers, if you want proof of the sheer anarchy of unfettered industrialization. There you will find the rule of a powerful and parasitic Geldadel, luxuriating in profits gained by the toil of an enslaved proletariat which earns just enough to return to the machines, day after miserable day.

"The stability of all social relationships is destroyed, the organic union of the industrial classes is decomposed, and society is divided into two masses of enemies, that find their center of gravity in the bourgeoisie and proletariat. An endless battle for external goods has endangered the inner values of the combatants; avarice on the one side and bitterness on the other have hardened their souls against the commands of moral law and even threatened the maintenance of legal order. All these evils are increasing, for the only remaining law of this endless movement declares: The rich shall become richer and the poor poorer... Moral rottenness, that is the great and horrible result of a false social order, that is the curse of liberalism." 1 
The poor but peaceful order of the guild system in Kurhessen, which lacked both the extremes of wealth and poverty and the ills consequent upon rapid economic change, could not do other than compare favorably with Marlo's terrible vision of industrialism. Marlo knew the guildsmen of the past had been as ruthless, on occasion, as any of the new capitalists, and had often conspired to rob their customers by price agreements. He himself told his readers how the guilds had often driven out, by force of arms, competitors who had refused to respect the guild monopolies, and he related the practice, common among the masters, of granting the Meisterwuerde for bribes or to favored relatives and friends who did not possess the necessary skill. Marlo knew the masters had often oppressed their journeymen and apprentices and had done the best they could to prevent all technical improvements which threatened their privileges. Furthermore, Marlo was no Luddite. Much of the curse of work, the ugliness of poverty, and the threat of starvation had been removed by industrial progress, and Marlo wanted such progress continued. He had observed the guild system too long to idealize it and long enough to understand why men had welcomed free enterprise. Accordingly, he did not ask for a return to the old guild system or even for a defense of its present remnants; instead, he hoped to show that its principles, if not its practices, could be used to end the chaos of uncontrolled economic expansion which seemed to threaten Germany.

His goal was a society in which "each, in so far as the laws of nature allow, will be given the power to use and increase his abilities, and to enjoy the whole fruit of his labors." 1 This ideal is a modification, of course, of those phrases commonly used by Socialists to indicate a society in which each would be granted the means justified by his abilities, and a reward equal to his work.

To begin with, Marlo proposed that all industry, trade, and agriculture be organized into national guilds. Each guild and each enterprise within a guild must have a legal limit imposed upon its size and activities beyond which it would not be allowed to expand. Industrial and agricultural enterprises would be limited to a certain number of workers, and each merchandising firm would be given a monopoly over a part of the national market. In this way the terror of unlimited expansion might be avoided. Those who amass more capital than is needed for their enterprise will be able to lend it to those who lack the money but not the ability to exploit their share of the national

' Ibid., 178-179. 
market. The state must keep interest rates low, and must also assure to each citizen a "sphere of activity" equivalent to his abilities. Would not, Marlo asked, such a state be able to ward off the wild struggle for markets and capital, the destructive competition, and the dangerous concentration of wealth and power in the hands of a few which have transformed modern societies into vast arenas in which occur chaotic struggles for survival?

Furthermore, and to counter the terrors of the decrease of wages, Marlo suggested: "The population will be constantly kept in harmony with the production of the means of subsistence." 2 Where each is assured of a certain share of the national income, he will find it easy to calculate how large his family can be. Also, no one will be allowed to marry before a certain age, and each couple will be required to deposit an Ebekapital to insure that their death or sickness does not impoverish their children. Every citizen will be expected to contribute to health, old age, and life insurance programs, and for those who do not find private employment, the state will provide public work. ${ }^{3}$

Like most Socialists of the day Marlo was not convinced of the value of "mere" political changes; nevertheless, he did provide for a democratically elected chamber of deputies, headed by a President or Kaiser. The real work of the government would be done, however, by an industrial or social chamber to be elected by the guilds voting according to profession, and with the stipulation that three-fifths of its members be selected from the industrial guilds. Theirs would be the task of planning the new organization of work and presenting it for approval to the political chamber. The political chamber would then order the plan put into effect by the minister of labor with his corps of experts - and, it is to be feared, a considerable body of men, armed to the teeth. Marlo was unaware of the powerful opposition his plan would arouse, nor did the technical difficulties dim his enthusiasm. The federalists, as he called his supporters:

"... were not concerning themselves with humanitarian dreams... they do not aim at founding a paradise, but a society in which only the natural world order will set the boundaries to the most free unfolding of all personalities. They are convinced that with the introduction of the federal order everyone will have a task measured to his abilities and a profit equal to his performance; involuntary poverty will end; a general well-being will replace luxury and poverty; dishonest profit through usury, stock-

1 Tbid., $365 \mathrm{ff}$.

Ibid., 369 .

Ibid., 365 ff. 
jobbing, and cheating will be ended in favor of honest gain; productive work will replace unproductive idleness; stable progress will be brought to all industry; national income will increase rapidly; all products will find the most adequate markets open to them; all capital will be offered the best investment opportunities... crimes will be reduced to an inconsiderable number; the military forces now needed to uphold an unjust social order will be unnecessary; the national debt will be reduced by more than half; the bases of a true, not just a formal, sovereignty of the people will be laid; the greatest guarantees for a lasting peace will be assured; and all that an organization of civil society can do to create the conditions for a moral society will have been done." 1

Lack of time, not uncertainty, prevented Marlo from giving all the details of this vast national division of labor in the first volume of his Organisation der Arbeit. He wanted it published in time to have some effect on those leading the revolutions of 1848 . Like Saint-Simon and Fourier, he envisioned a world of unlimited possibility, because he did not think the laws of things superior to the plans of men. To Marlo, man, driven by a desire to free himself from ancient restrictions, had stumbled blindly into free enterprise. If a blind stumbler could accomplish so much, what limits were there to the far-sighted planner of a rational economy?

\section{III}

It might seem to many that Marlo's federalism is just another curious Utopia created by an impractical eccentric, and perhaps there are those who find his certainty that men would one day create such an organization of work hardly credible. Still, we should remember that in those hopeful days one had to be utopian to be realistic. Was anything achieved in 1848 by those who did not demand too much? And if the Forty-eighters are to be called unrealistic because they did not get all they asked for, was there ever a realist? Certainly their experience did not teach them the power of given circumstances. The King of France, the Emperor of Austria, Metternich, all swept from power; the King of Prussia humbled, France a republic, and Germany represented by a national Parliament - who was utopian enough to expect all this in 1847 ?

Surely, then, Marlo cannot be held impractical because he hoped to persuade others to work for his federalism. And in his own Kurhessen, events were such as to persuade him that the most propitious moment to gain public attention had arrived. His fellow citizens were famous 1 Ibid., 373-374. 
for their obedience and loyalty to one of the most reactionary Princes of Germany, the Elector Friedrich Wilhelm; nevertheless, in 1848 , the Elector found himself threatened with violence when he sought to deprive his subjects of rights acquired by the Constitution of I 83 I. In March crowds swarmed about the royal residence, and their leaders demanded liberal ministers, constitutionalism, and freedom of the press, religion, and opinion. Minister Scheffer, Kurhessen's Metternich, fled, and the Elector appointed a "March Ministry" of liberal constitutionalists. The pattern was being repeated in all Germany, and it was a pattern fit to inspire utopians. ${ }^{1}$

Still, the majority of revolutionists in Kurhessen, as in Germany, were liberals and did not share Marlo's desire for extensive social reform. Did they not intend to introduce the very social order he feared? Consequently, Marlo joined the radical party in Kurhessen, the Liberal Democrats (Freisinnige Demokraten). ${ }^{2}$ His fellow democrats were so impressed with Marlo's federalism that they made him a member of their nominating committee, allowed him to write their party platform, and chose him as their candidate for election to the Parliament in Frankfort. The weakness of the left, however, as well as Marlo's lack of appeal to the voters was shown by the election results: 7,800 to 75 , in favor of the liberal candidate, Philipp Schwarzenberg! Marlo was no politician. He never mastered the art of persuasion. He never learned to sway his audience by carefully leading them from their ideas to his. His campaign speeches, like his party platform, were simply matter of fact outlines of his new organization of labor. With such clumsy tactics he could not even hope to gain the support of the independent radicals, for he left them only two choices, his Utopia or a vote for the liberals.

Marlo's overwhelming defeat, however, indicates much more than his lack of political sense; it illustrates the fundamental cleavage between liberals and social reformers - a cleavage which was, in the end, to prove of great value to the conservative cause. As Veit Valentin has shown, Marlo's debates during the election campaign with one of Kurhessen's leading liberals, Friedrich Oetker, illustrates the dimensions of this fatal gap between liberals and radicals in $1848 .^{3}$.The liberals asked for general freedom embodied in constitutional guarantees, and they insisted that the right of private property be similarly guaranteed.

1 Heinrich Graefe, Kurhessen seit I 848, in: Gegenwart, VI, I 85 I.

2 W. Biermann, Karl Winkelblech (Karl Marlo), Leipzig, I g09. Unless otherwise indicated, this has been the source for my biographical remarks.

${ }^{3}$ Veit Valentin, 1848, Chapters of German History, London, I940, p. 266 ff. Valentin's remarks on the history of the radical movement in 1848 are most valuable. 
For the guildsmen (as for the peasantry) such respect for private property could only be seen as a threat. To free industry, for example, from guild regulations would mean to transform the proud and independent master craftsman into an industrial wage-slave. As Marlo wrote with reference to France and England:

"They [the liberals] wanted to make work free, and have bowed it under the yoke of capital; they wanted to unchain all powers, and have beaten men down with the chains of misery; they wanted to free the serf from bondage, and have robbed him of the very ground on which he stood; they wanted the well-being of all, and have created only the extremes of poverty and luxury... they wanted to destroy all monopolies, and have replaced them with the monster monopoly of capital... they wanted education to be the property of all, and have made it the privilege of wealth; they wanted the highest moral improvement of society, and have plunged it in moral rottenness; in short, they wanted limitless freedom, and have created the most abusive thralldom..." 1

In spite of these differences, when the citizens of Kurhessen met to elect a People's Assembly to oversee the work of the new government, Marlo was chosen. And through his work on the Committee for Industry of the Assembly, he was soon given the opportunity to meet men far more receptive to his federalism than the liberals of Kurhessen.

On May 30, I848 Marlo was chosen by the People's Assembly to represent them at a meeting of guildsmen in Hamburg, the First Representative Assembly of the North German Guild and Industrial Classes. This assembly, the most important of many such meetings all over Germany, had invited representatives of many guilds with the hope of starting a nation-wide movement against the introduction of unrestricted free enterprise.

It was a splendid opportunity, and Marlo made the most of it. Biermann, his biographer, reports that Marlo's speeches to the Assembly were the only ones followed by "stormy approval", and well they might be, for most of the two hundred guildsmen learned from him that they were not convened merely to defend the old order but to create a new one. In his first speech Marlo announced to the guildsmen that only a comprehensive guild organization embracing all industry could protect them and Germany from the fate of France and England and the "dangers of communism". ${ }^{2} \mathrm{He}$ asked the guildsmen

1 Marlo, op. cit., pp. 297-298.

2 Verhandlung der ersten A bgeordneten-Versammlung des Nord-Deutschen Handwerkerund Gewerbestandes zu Hamburg, June I 848 (Meine und Schirges, Hamburg, I848). See Biermann, op. cit., $\Pi$, pp. 57-58. 
to convene an industrial parliament in Frankfort a.M. to meet in the late summer of the year with representatives from all the guilds of Germany. A few of the masters, however, reminded Marlo that only the Frankfort Parliament itself had the power to make such an industrial chamber part of the government of Germany. Even so, they suggested further, the guildsmen might call for a private assembly which, even though without constitutional sanction, might have a great effect on public opinion. Thereupon the assembled guildsmen voted for this proposal, set July I , 1848, as the opening date of the new congress, and charged it with presenting a guild constitution for all Germany to Parliament and the nation. ${ }^{1}$

Encouraged by his success at Hamburg, Marlo was convinced that his federalism would soon become a national cause. In his last speech before the assembled guildsmen, Marlo remarked, after noting that the Frankfort Parliament had been called to decide the political form of Germany:

"The task of (our) congress will be far more important. It has the duty of forming a public opinion about social reform. It is to the nation then that it must present its recommendations. Once public opinion has been formed, once the people know with certainty what they want, then they will know how to find the men who will carry out their will in the following parliamentary elections. If a decisive majority of the nation arrives at a common conviction, then the guarantee of a peaceful development will be won and Germany will come out of her crisis without a civil war.... For the greatest of all successes was already accomplished when the nation, through its Parliament, declared itself sovereign. From now on and for all time the Germans will have no other masters over them but God and conscience."2

The Congress at Frankfort did not fulfill Marlo's hopes. Against his advice, the masters excluded industrial workers and even their own journeymen from voice and vote, and all but five of those present were master-guildsmen. ${ }^{3}$ Marlo warned the masters: how could they hope to gain acceptance for their proposals to reorganize all German industry if they did not consult with representatives of the new factories? The masters surrendered their ideal because they did not wish to share their power, and they excluded their journeymen because they knew the journeymen would lose no opportunity of making known their grievances against the masters. Allowed to remain at the Congress but denied the right to debate or vote, the journeymen, on

1 Biermann, op. cit., II, 66-67.

- Biermann, Ibid., II, 69.

Ibid., II. 
August 4th, walked out, unwilling to give sanction to a Congress over whose decisions they had no influence. ${ }^{1}$ In the paternalistic words of President May, the masters found their justification. "We are dealing here with a relationship like that of a father to his son." 2

Still more damaging to Marlo's hopes, the masters began to fear (quite rightly) that Marlo's plan for a total reform of German industry could not take into account their petty monopolies and might even be more dangerous than the introduction of free enterprise! At Hamburg the masters had been proud of "our professor"; at Frankfort some openly doubted the abilities of a man without practical experience in the guilds. Still Marlo persisted, and throughout the debates he and a small group of masters tried to persuade the Congress of their duty to revolutionize the industrial system of Germany. Marlo told them, in his most effective speech, of a woodworking factory he had visited whose workers were former master cabinet makers driven out of business by the competition of that same factory. "Count the tears of those masters," he pleaded, "and resolve to set boundaries to the expansion of each enterprise." 3

In spite of Marlo's efforts, the masters' final Plan for a General Guild and Industrial Order for Germany, was no more than an impertinent and pitiful attempt to subject the nation to the privileges of the masters. Each worker, they insisted, should be a guild member, but the masters should have sole power within the guilds. They did ask for Marlo's Industrial Parliament, but they insisted that only the masters should elect its members. Bereft of all influence, the journeymen and apprentices were even to be required to carry workbooks in which their ability, industry, and moral fitness were to be duly registered by the masters. Furthermore, no new industry was to be allowed to produce articles already manufactured by the guilds, and all industries were to be heavily taxed in favor of the guilds'. ${ }^{4}$ The local newspapers were quick to poke fun at the masters' desperate attempts to stave off the Industrial Revolution, and in an Appendix to Volume One of the Organisation der Arbeit, Marlo expressed his own disappointment with their decisions. 5

Among the journeymen who had walked out of the masters' Congress, however, Marlo found the sort of followers he required.

1 Verhandlung des ersten Deutschen Handwerker- und Gewerbe-Kongresses zu Frankfurt a. M., Schirges, Editor (Darmstadt: Papst, 1848) p. 139.

2 Ibid., 23.

3 Ibid., 12 I.

4 Entwurf einer Allgemeinen Handwerker- und Gewerbe- Ordnung fuer Deutschland, Frankfurt a.M., Naumann, 1848 .

${ }^{5}$ Marlo, op.cit., I, Part One, I 86-187. 
They started a journeymen's Congress of their own and soon renamed it the General German Workers' Congress in order to advertise their interest in all workers, regardless of guild status. Marlo joined the Workers' Congress, and praised their views in the same Appendix in which he criticized the masters. The Workers' Congress:

"... raised its view over the narrow limits the others had set to their effectiveness, and concerned itself with the social question in its entirety, and planned a social program which contains essentially the leading principles whose scientific proof and special consideration is the purpose of this work." 1

He could give no higher praise.

The members of the General Workers' Congress agreed with Marlo; the masters were too much interested in maintaining their privileges to plan a guild organization in the interest of all German workers. Marlo did not need to persuade these men of the need for mass support; not only did they call for all workers to send representatives, they were prepared to admit into the Arbeiterbund as members with full rights, "not only workers but also friends of labor from all social classes: artists, scholars, merchants, craftsmen, factory owners, etc." 2 The workers repeated the strictures of the masters against free enterprise but, they insisted, the new guild system must be more than merely a reorganization of the present guilds, rather, it must be extended to include all branches of industry, and also trade and agriculture. ${ }^{3}$

Although the workers did not publish the minutes of their meetings, the influence of Marlo is strikingly evident throughout their other published documents. Phrases, paragraphs, and pages seem to have been lifted bodily from the manuscript of the Organisation der Arbeit. [We demand] "the introduction of a new guild constitution, a new organization of work completely different from the old one, one that is adjusted to our highly complicated industrial circumstances, includes all social enterprises... assures to every member of civil society a sphere of activity corresponding to his work power, makes the progress of industry stable and continuous, makes the success of producers depend on their industry and ability, stops all dishonest profit through usury, stock-jobbing, and cheating, avoids the bankruptcy of the innocent in so far as is possible, and makes every new invention equally useful to its inventor and his competitors." 4

The hope, the details, and the succession of dependent clauses are

1 Marlo, Ibid., 186.

2 Biermann, op. cit., 459.

3 Biermann, Ibid., 455 .

4 Biermann, Ibid. 440. 
all Marlo's. Furthermore, the workers demanded that each business must have a Geschaeftsgrenze - one of Marlo's favorite words - and an Industrial Parliament as well as a Ministry of Labor to carry out its decisions. The workers countered the monopolistic proposals of the masters by providing that all workers were to have the right to elect members of the Industrial Parliament, and by putting the administrative, judicial, and examining power of the guilds under the control of boards in which the masters could not even hope for a majority. Having finished their task, the workers handed their recommendations to representatives of the Frankfort Parliament and returned to their jobs.

I 848 seemed to hold much promise for Marlo and the guildsmen. As Mr. Hamerow noted, the two assemblies at which Marlo had had the most influence could fairly claim to represent the opinions of the guildsmen of Germany. Although many of the states acknowledged receipt of the guildsmen's petitions merely by appointing the usual committees of investigation, Prussia, Bavaria, Hanover, and Frankfort passed laws favoring the guilds and restricting free enterprise. ${ }^{1}$ Moreover, a committee of the Frankfort Parliament was appointed to draw up a code of guild regulations for Germany. Marlo returned to Kassel, certain that he could count the majority of German guildsmen and many workers among his federalists. Of the meetings in Frankfort, he wrote:

"The far-sighted observer will know that such close agreement between the convictions of whole Volksklassen against free competition as was here revealed, must be of the greatest significance for the future formation of our social relationships." 2 Marlo's first disappointment came when he attempted to extend the influence of the General Workers' Union, which, in August of 1848, had accepted his federalism as part of its program. They did not represent more than a tiny fraction of the workers of Germany; still, the possibilities for greatly increasing their numbers seemed excellent. Workers' groups were being organized in every part of Germany. The General Workers' Union began to compete with various other associations for new members. Marlo himself was sent by the Union to represent them in Heidelberg, at a meeting of south German workers, who, deciding to merge with a larger organization, had invited both Marlo's Union and a north German workers' association, the Verbruederung, to send representatives to their assembly. Accordingly,

${ }^{1}$ E. F. Goldschmidt, Die Deutsche Handwerker-Bewegung bis zum Siege der Gewerbefreiheit, Munich, I916.

2 Marlo, op. cit., I87. 
Marlo and Stephan Born, a well-known officer of the Verbruederung, met in debate on January 28 and $29,1849 .{ }^{1}$

Born described the debates in his Erinnerungen, published in $1898 .^{2}$ To him, Marlo's federalism was no more than an attempt to preserve the monopolies of the master guildsmen, and Born prided himself on representing the interests of the industrial workers. It is true that the Verbruederung was less interested than the Union in forming a new guild system, and stressed instead the need for industrial unions, minimum wage laws, collective bargaining and a progressive income tax. Still, most of the members of the Verbruederung were guildsmen and they also expressed in their program a desire to maintain much of the guild regulations of Germany. Furthermore, the program of the General Workers' Union also included demands more appealing to industrial workers, but Marlo thought little of them and did not mention them in the debates. Most of his audience at Heidelberg were not guildsmen or were not high enough in the guild hierarchy to feel any loyalty to the system. Consequently, they greeted his federalism with indifference. In fact, when pressed by Born, Marlo had to admit the excellence of the proposals of the Verbruederung and could only add lamely, "That he viewed his system as a later task for the society of the future." With this the debates closed and the workers voted to join the Verbruederung. Marlo left before the vote was taken, evidently aware that he had been defeated. The Verbruederung, and not the General Workers' Union, went on to great successes during the next two years. ${ }^{3}$

From I 849 on, Marlo discovered that although it was easy to convince the hard-pressed guildsmen of the need for a general extension of the guild-system, it was quite another matter to persuade those whose interests were not bound up with the old order. As a reporter for the Frankfurter Journal observed after hearing a speech of Marlo's: "In our day nothing is more rare than a political economist who is against free enterprise."4

It is true that the Frankfort Parliament appointed a committee to draw up a set of guild regulations for Germany, but the task proved too

1 Georg Adler, Die Geschichte der ersten sozialpolitischen Arbeiterbewegung in Deutschland, Berlin, I 885 , pp. $18 \mathrm{Iff}$.

Biermann, op. cit., II, p. $288 \mathrm{ff}$.

Max Quarck, Die erste Deutsche Arbeiterbewegung: Geschichte der Arbeiterverbruederung 1848/49, Leipzig I924, Pp. 225-230.

2 Stephan Born, Erinnerungen eines Achtundvierzigers, Leipzig, 1898, pp. 19xff.

${ }^{3}$ Quarck, op.cit., 230.

1 Frankfurter Journal, 222, Erste Beilage, (12 August, 1848) p. I. 
difficult. It would have been an immense undertaking even to codify existing guild regulations, for they differed from state to state, town to town, and village to village. It would not have been enough simply to regulate existing guilds, for, of course, such regulation would not help the guildsmen if free enterprise were not forbidden. Moreover, not only did the guild system violate the liberals' desire for economic freedom, it also seemed unworkable, inefficient and authoritarian. Even those liberals who sympathized with the plight of the lower classes did not regard the masters' treatment of their journeymen as any better than the treatment accorded the workers in the new industries not controlled by the guilds. And in this, the liberals were not wrong.

It is a paradox of the guild movement that although it was stimulated by the liberal revolutions of 1848 , any support that it might receive was more likely to come from the conservatives. Men like F. J. Stahl, the intellectual leader of the Prussian conservatives, and those who belonged to the reactionary Gerlacb-Kreise and the Kreuzzeitung party regarded the artisans and the guilds as integral and necessary parts of any just and stable social order. For the German rightists were anticapitalist and opposed to the liberal industrialists as thoroughly as were the masters. Indeed, when the reaction of the fifties set in, conservatives in many states passed legislation favoring the guilds.

During the sixties, however, a growing alliance between the conservatives and the national liberals (who had shed the philosophical idealism of the pre-' 48 liberal movement), an alliance consecrated by Bismarck's victories, brought about the defeat of guildism. The Conservatives were willing to grant modified laissez-faire in return for the Liberal surrender to the old regime of Prussia. As early as 18 io the Stein-Hardenberg laws had made it possible to start many enterprises without entering a guild, and, if the product were not one which might endanger public health, without passing an examination. ${ }^{1}$ Thereafter, no German state banned free enterprise outright, and in 1869 the North German Union adopted it without restriction.

As for the general public, they showed little interest in continuing the guild system. There had been, of course, an economic crisis in 1847 and ' 48 , but only the guildsmen attributed it to the introduction of free enterprise. Nor did the guilds seem to suffer from the effects of unrestricted competition; the French had brought free enterprise to the Bavarian Rhineland forty years earlier, but the Bavarian guilds

1 Schmoller, op. cit., 95 . 
were among the most numerous and prosperous of Germany. ${ }^{1}$ It is true that the new industries had taken some of the markets of the guilds, but it is also true that they more often produced articles not offered by the guilds. Moreover, such enterprises often created new markets for the guilds, and many masters found a lively trade producing small parts for the entrepreneurs or consumer goods for their workers. Most impressive of all, the factories produced more and cheaper goods than the guilds could supply. Such pressure was irresistable. The day of the guilds was over.

After I 849, Marlo took no part in workers' organizations. In I 848 he was elected to the Landtag of Kurhessen and there he remained, one of the leaders of the Radical Democrats, until he refused election in the summer of 1849 . The overwhelming majority of his fellow delegates were liberals and had no patience with his utopianism. Disgusted with the turn of events, Marlo returned to his manuscript. When the reaction came to Kurhessen in February of 1850 Marlo was punished for his radicalism by being forced to quarter troops of the reactionary Austrian Bund in his house, and he was the victim of a lengthy trial for treason. Although he was finally acquitted ( 1853 ) during the trial he had been suspended without pay from his post. Even right-wing radicalism was too much for the timid and victorious conservatives!

Marlo has never been a well-known name even among historians of German socialism. ${ }^{2}$ In 1880 , however, the political economist and philosopher of the organic state, Schaeffle, together with Marlo's wife, brought out a second edition of the Untersucbungen ueber die Organisation der Arbeit with some additions from Marlo's Nachlass. ${ }^{3}$ In vain; few read it even during the revival of guild socialism near the end of the century. Biermann, Marlo's biographer, attributed Marlo's lack of fame to the public's commitment to economic liberalism. ${ }^{4}$ That is one reason, perhaps, but it is not enough, for, of course, attacks on free enterprise were popular throughout the nineteenth century. It is certain, however, that the last half of the nineteenth century was a difficult time for anyone who wished to convince others of the vitality of the guild system - especially when even the guildsmen were not willing to surrender their monopolies in order to adjust guild regulations to a new industrial order. Still, even had there been a public

1 Schmoller, Ibid., 108.

2 G. D. H. Cole, however, has presented an excellent brief exposition of Marlo's ideas in: History of Socialist Thought, New York, I953-56, I.

${ }^{3}$ Karl Marlo, Untersuchungen ueber die Organisation der Arbeit; oder, System der Weltoekonomie, 2te Vervollstaendigte Auflage, Tuebingen, H. Laupp, r884-r886.

- Biermann, op. cit., II, 398-401. 
ready to be so convinced, Marlo's later works - turgid and pedantic as they are - would only have sent them elsewhere.

There are other important reasons why Marlo's work remains merely a document illustrating but not influencing an era. His first work might have gained a considerable following had it been published before 1850 , but by then it was too late; utopianism of all kinds was one of the first victims of the reaction. Furthermore, during the latter half of the century, Marlo's fellow reformers were no longer interested in returning to an old economic order, but in reforming or even replacing a new industrial order; indeed, like the Marxists later, many Socialists were certain that because of its productive power, capitalism was, if not a necessary, then certainly a desirable stage in "world history". In the later volumes of his work Marlo attempted to deny the productive efficiency of unregulated competition but in the booming Germany of the sixties and seventies such a view could hardly become popular. Marlo's influence was confined to the assembled guildsmen in Hamburg and Frankfort during the hopeful months of I 848. Marlo's failure was tied up with the failure of the guild movement; for in spite of his attempt to transform the guildsmen's private interest into public principle, he became known as merely a defender of an outmoded system of control and monopoly which, both liberals and reformers agreed, could have no place in Germany's Industrial Revolution. 